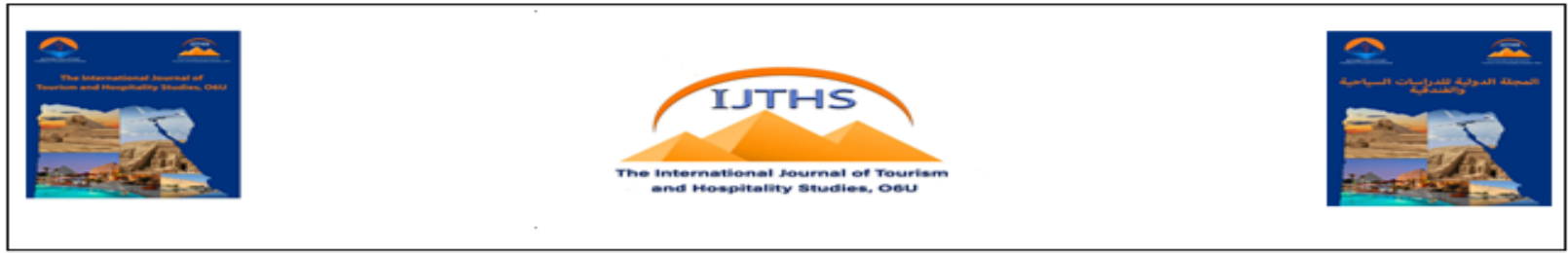

\title{
The Grand Egyptian Museum: Implications for Sustainability
}

\section{Prof. Dr. Azza Saad Mohamed Attia}

Faculty of Tourism \& Hotel

Management, October 6

University, Egypt

\section{Prof. Dr. Mona Taha Hussein}

Faculty of Tourism \& Hotel Management, October 6

University, Egypt

\section{Prof. Dr. Noha Saad El- Shaer}

Faculty of Tourism \& Hotel Management, October 6 University, Egypt

\section{ARTICLE INFO \\ Keywords: \\ Egyptian Community, Grand Egyptian Museum, Museum Development, Sustainability.}

\section{(IJTHS), O6U}

Vol. 1, No. 1, June,2021, pp. 13-24.

\section{Abstract}

Purpose - The sustainability and procedures that are taken by all public and private authorities in a given region (Egypt) dictate the type of development in that area (around the Grand Egyptian Museum "GEM"). From among those authorities, the role that should be played by museums is questioned. The Grand Egyptian Museum stands as a unique institution that possesses the potentiality of developing and explaining new significant knowledge to the society. How the Grand Egyptian Museum will contribute the sustainability in the Egyptian community. Sustainability implications after the GEM become more and more important. This paper will review and scope on three areas: first the sustainability in the architecture of the museum, second the sustainable accommodation rounding the museum, and changing the Egyptian tourism map and the travel agencies programs.

Design/methodology/approach - The GEM is considered as a unique museum. As a result, we should treat it as a unique case study, Interviews with International and Egyptian experts were the methodology of the research.

Research Limitations/Implications - Investigated the sustainable development in the Egyptian society and how the GEM delivering value internationally and nationally. 


\section{Introduction}

The role of culture and heritage in sustainable development was recognized by the United Nations in the 2030 Agenda along with the seventeen goals of the Sustainable Development Goals "SDGs" (UN Report, 2021).

The review of the international literature reveals that the issue of sustainability in museums has not been sufficiently tackled. This situation may be due to the fact that programs designed to promote sustainable development include just few museums. (Tonino et al, 2016).

The subject of museums and the roles they play in relation to their local territory, economies, and communities, in general, seem to draw great interest on both the theoretical as well as practical levels. Taking into consideration the role museums could play in relation to the fields of cultural tourism, cultural economics, urban planning studies and managerial implications, this current issue of museums and territories become a focus (Codignola and Mariani, 2017).

According to Gunay (2012), museums have begun to evolve as service institutions that contribute to the advancement of society rather than collections and storage facilities. Museums have evolved from being just venues where art and scientific goods are shown, and all historical treasures are preserved to being informal teaching spaces and tools for disseminating the message.

In this way, the museum (inside the show) becomes an opportunity for visitors' appreciation to be enhanced further (Colbert, 2003).

This context explains why museums and galleries provide a variety of services (e.g., educational programs, bars, restaurants, bookshops, events, and so on) geared at improving the overall experience in terms of accessibility and varied meanings conveyed to visitors. Furthermore, museums contribute to a destination's overall tourism product by providing a set of feelings associated with a specific theme. Egypt will be able to become a major global hub for Pharaonic history, as well as a must-see destination for Egyptologists, thanks to the Grand Egyptian Museum. The museum intends to capture the diversity of Egypt's heritage of monuments and arts, which must be displayed in a single location in order to protect and preserve this vast legacy (Tuft \& Milne, 1999).

The Pyramids and the Grand Egyptian Museum have a strong visual affinity, In effect; it unites the Museum and the ancient marvel on a single site, establishing a formal dialogue. The summit of the Museum level will provide an unobstructed view of the three Pyramids. The GEM is a window to the past, nestled between the ancient Great Pyramids and the modern metropolis of Cairo, at the crossroads of the parched desert and the fertile floodplain. (Administration \& Conservation Center: El Mathf El Masry El Kebir, 2020).

\section{Literature Review}

\section{A sustainable overview of the Grand Egyptian Museum (GEM)}

The 17 Sustainable Development Goals and 169 targets, according to the United Nations (2015), reflect the scope and ambition of this new universal Agenda. All SDGs, on the other hand, might be based on the 2030 Agenda's"5 Ps" (People, Planet, Prosperity, Peace and Partnerships). 
Some members of the International Council on Monuments and Sites (ICOMOS) think that heritage, natural and cultural, physical and intangible, is critical achieving the United Nations' Sustainable Development Goals (Sophia Labadi, 2021).

According to International Council of Museums (ICOM, 2013), a museum's objective is to serve the development of society by obtaining, conserving, investigating, conveying, and exhibiting "the tangible and intangible evidence of people and their environment. Museums have a crucial role to play in illustrating the connections between the social, economic, and environmental aspects of sustainable development, and in making knowledge about the issues more broadly available.

According to Department for Digital, Culture, Media \& Sport (DCMS, 2004). The Grand Egyptian Museum, set to open in 2022, will depict Pharaonic Egypt's historical, cultural, and geographical evolution as documented by archaeological findings, moreover historical, and epigraphic sources. The collections and individual artifacts will be used as tools to depict the evolution of ancient civilization in all of its forms. Objects will be displayed in ways that accentuate their aesthetic worth, even if the shows' major subject will not be art history in the usual sense.

In addition, supplementary materials such as photographs, drawings, and maps will be included with the artifacts, enhancing their informational worth. The museum will be divided into five sections based on five themes (Hawas, 2005)

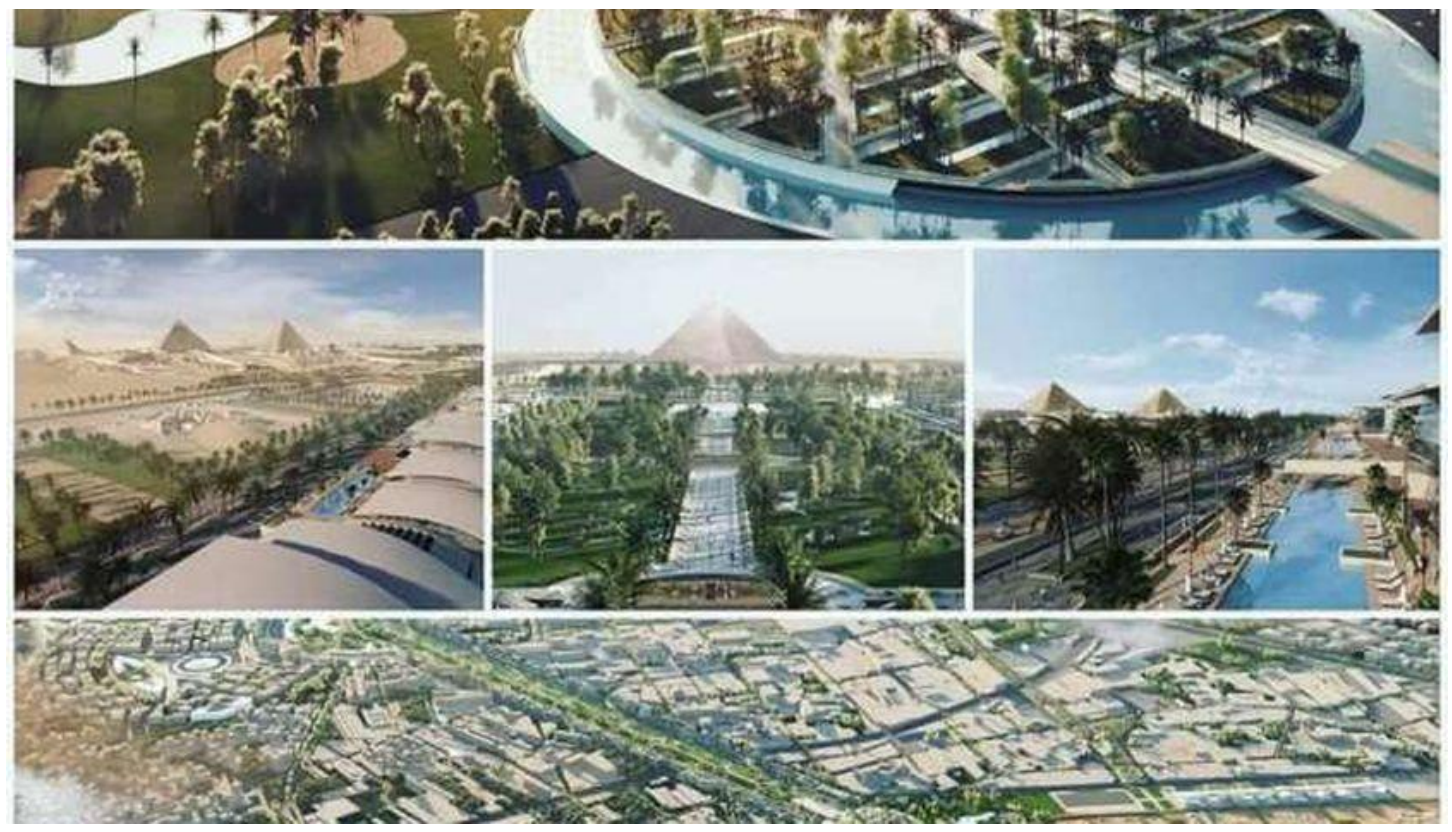

Source: (The Egyptian electronic portal of the Egyptian Ministry of Tourism and Antiquities, 2020)

Constraining measures, rather than "taking advantage" of opportunities for "controllable" urban development, such as the implementation of major projects with international agencies to incorporate upgrading elements that can irradiate the surrounding territory" (Bonifica, 1999). 
The building, which resembles a truncated triangle, is inspired by the pyramids. Its north and south walls are aligned with Khufu's and Menkaure's pyramids. The structure is situated in front of a large square. A vast atrium on the inside will serve as an exhibition place for enormous statues. The facility also includes a convention Centre, an Educational Centre, and workshop space (Administration \& Conservation Center: El Mathf El Masry El Kebir, 2020).

The Grand Museum of Egypt was designed with the goal of combining expressive features with utilitarian precision. The concept makes a strong literary statement, but the architectural programmer recommends a low-key approach to the location. The project and its significance as a new 'edge' to the Giza plateau can easily be highlighted. It also features a high level of lighting solutions and has sufficiently addressed the information and communication system at this early stage of design. It allows for easy access to the museum's numerous galleries via the main lobby, the grand staircase, and other areas. However, due to its processional nature, the staircase itself requires further investigation (Mansour, 2005).

The purpose for building the Gem Museum underground and surrounding it with a roof garden is to give shade inside the inverted tiered building, and the second concept is to create an oasis in the desert by encircling the museum with water (Abdeen, 2021).

\section{The Role of the GEM in the Egyptian Society}

Museum is a non-profit organization that serves society and welcomes visitors. The major goal of this organization is to acquire, maintain, conserve, and show the tangible and intangible historic heritage of the human race for educational, recreational, economic, and other purposes (ICOM, 2007).

Museums are products of society, and when they are part of a professional development program, they are actively serving society. Responding to obvious needs, such as education, entertainment, and civic pride, as well as the conscious affirmation of shared societal values, is what service entails. As a civilization evolves, so does its culture in order to meet changing demand as a result, the museum's role must adapt in order for it to continue to serve society (Abdel Minuid, 2005). Similarly, El Sheikh (2020) noted that a museum's function is not limited to collecting, preserving, and storing pieces of heritage, but also serves to manage and maintain a nation's identity, strengthen and enhance the tourism industry, and impart knowledge to Citizens.

One of the hallmarks of this period was a large investment in public spending, and governments had ample resources to respond to changing community demands. Initially focused on fundamental needs, government involvement grew to include expanded welfare and social services, subsidies for all forms of the arts, consumer protection, and environmental protection (Sandell and Janes, 2007).

Museums assist to the development of a broad cultural structure aiming at disseminating experiences and information while also providing "hereness" sensations. Moreover, museums contribute to the growth of a broad cultural structure that aims to disseminate experiences and information while also creating "hereness" sensations (Herreman, 1998). 
Science museums are thought of as learning environments. They project lived experiences that go beyond delight and entertainment. On the basis of cultural and social paradigms, programs and educational projects are developed (Marandino, 2005).

Social impact: Enhance the colossal pyramid plateau's urban identity by improving its health service conditions. Providing a safe system with a high level of security (Abdeen, 2021). Sandell and Janes (2007), explored the unique and long-term benefits of museums contribute to society. Table (1) shows these benefits.

\section{Table (1) Long-term social value of participation in arts projects}

\begin{tabular}{|c|c|c|c|}
\hline $\begin{array}{c}\text { Personal } \\
\text { development }\end{array}$ & Social cohesion & $\begin{array}{c}\text { Community } \\
\text { empowerment }\end{array}$ & $\begin{array}{c}\text { Local image and } \\
\text { identity }\end{array}$ \\
\hline $\begin{array}{l}\text { - Increased personal } \\
\text { confidence and self- } \\
\text { worth }\end{array}$ & $\begin{array}{l}\text { - Reduced social } \\
\text { isolation }\end{array}$ & $\begin{array}{l}\text { - Built community } \\
\text { organizational capacity }\end{array}$ & $\begin{array}{l}\text { - Developed pride } \\
\text { in local traditions } \\
\text { and cultures }\end{array}$ \\
\hline $\begin{array}{l}\text { - Extended involvement } \\
\text { in social activity }\end{array}$ & $\begin{array}{l}\text { - Developed } \\
\text { community } \\
\text { networks } \\
\end{array}$ & $\begin{array}{l}\text { Encouraged local self- } \\
\text { reliance }\end{array}$ & $\begin{array}{l}-\begin{array}{l}\text { Ensure the sense } \\
\text { of belonging in } \\
\text { society }\end{array} \\
\end{array}$ \\
\hline $\begin{array}{l}\text { - Make a loud and } \\
\text { active voice for people }\end{array}$ & $\begin{array}{l}\text { - Promoted tolerance } \\
\text { \& conflict } \\
\text { resolution }\end{array}$ & $\begin{array}{l}\text { Helped people extend } \\
\text { control over their lives }\end{array}$ & $\begin{array}{l}- \text { Created } \\
\text { community } \\
\text { traditions }\end{array}$ \\
\hline $\begin{array}{l}\text { - Stimulated interest in } \\
\text { arts }\end{array}$ & $\begin{array}{l}\text { - Show a forum for } \\
\text { multicultural } \\
\text { understanding }\end{array}$ & $\begin{array}{l}\text { - Provided insight into } \\
\text { political and social } \\
\text { ideas }\end{array}$ & $\begin{array}{ll}- & \text { Involved residents } \\
\text { in environmental } \\
\text { improvement }\end{array}$ \\
\hline $\begin{array}{l}- \text { Provided forums to } \\
\text { explore personal rights }\end{array}$ & $\begin{array}{l}\text { - Helped validate the } \\
\text { contribution of a } \\
\text { whole community }\end{array}$ & $\begin{array}{l}\text { - Consultation centers } \\
\text { for local community }\end{array}$ & $\begin{array}{l}\text { Provided a basis } \\
\text { for developing } \\
\text { community } \\
\text { activities }\end{array}$ \\
\hline 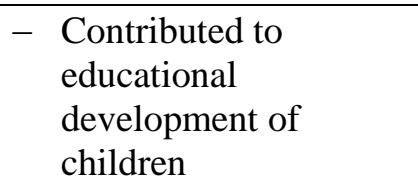 & $\begin{array}{l}- \text { Promoted cross- } \\
\text { cultural contact and } \\
\text { co-operation }\end{array}$ & 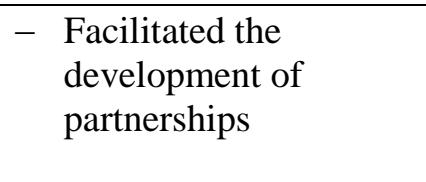 & $\begin{array}{l}- \text { Improved } \\
\text { perceptions of } \\
\text { marginalized } \\
\text { groups }\end{array}$ \\
\hline $\begin{array}{l}\text { Motivate communities } \\
\text { to educate and train }\end{array}$ & $\begin{array}{l}- \text { Promoted contact } \\
\text { across generations }\end{array}$ & $\begin{array}{l}- \text { Built support for } \\
\text { community projects }\end{array}$ & $\begin{array}{l}\text { Helped transform } \\
\text { the image of } \\
\text { public bodies }\end{array}$ \\
\hline $\begin{array}{l}\text { - Build new skills and } \\
\text { work experience }\end{array}$ & $\begin{array}{l}\text { - Helped address } \\
\text { issues of crime }\end{array}$ & $\begin{array}{l}- \text { Strengthened } \\
\text { community co- } \\
\text { operation }\end{array}$ & $\begin{array}{l}\text { - People } \\
\text { satisfaction }\end{array}$ \\
\hline $\begin{array}{l}\text { - Contributed to } \\
\text { people's employability }\end{array}$ & 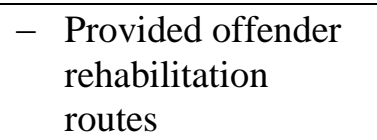 & & \\
\hline
\end{tabular}

Source: Sandell and Janes (2007)

The mission of the GEM is to be one of the developments of a sustainable module for a world destination. That will be by achieving and exhibiting unique events, promoting the heritage of Egypt locally and internationally, and merging cultural, arts, and entertainment components. Also, to create an exciting visitor experience, develop research and innovation in the field of cultural heritage and apply the operational standards and technologies (The Grand Egyptian Museum: The Style mate, Art \& Culture, Design, 2020). 
The GEM should be seen as an opportunity for enhancing the quality of life for the social groups residing in the neighborhood rather than a cause of negative social transformations. A museum plays a great socio-cultural role and participates in developing the cultural and social standards of the community within which it is established (Mazen, 2006).

\section{Virtual GEM a New Face of Sustainability}

Styliani, (2009), defined the virtual museum groups of digitally recorded images, sounds, documents and historical and scientific data that are accessed through many ways of electronic media.

Schweibenz, (2019), stated that because of the growth of acceptance of virtual reality technology in general, the virtual museums have become an important subject again.

Lopatovska, (2015), ensured that recently museum has begun to improve its online interactions with visitors and communicate with their virtual collections. The museums virtual visitors expect websites to encourage learning, to be vital, easily accessible, make pleasing visuals. While museums developing and utilizing the online presence in many ways, museums aim to motivate users to interact and engage with their collections.

Daniela (2020), illustrated the benefits of virtual museums:

1. To interest society in museum collections because virtual collections allow the community to explore other dimensions of culture.

2. To show artifacts that would not have been displayed.

3. To preserve and allow access to a variety of events that people could visit virtually without time and national boundaries.

4. To continue the development of the local community.

\section{Changing the Entertainment and Accommodation Facilities after GEM}

In 2010, there were 42895537 tourists entered the Egyptian Museum (El Tahrir Square). In 2011, the number of tourists dramatically decreased to reach (12604891) tourists (due to the Egyptian Revolution). Then the numbers increased to be (17211417) and (22512320) in 2012 and 2013 (Attia et al, 2015).

The upgrading of the road networks and transportation modes in the area is expected while there have been plans to allow the underground metro to reach the GEM site. It is expected that Cairo- Alexandria desert road would also have its share of improvement. It is expected that such important avenue would become wider with fewer intersections. The benefits would also reach the nearby informal residential areas. Environmental recovery and urban upgrading in the Nazlat El Semman will be settled. (Attaia and Abdel Kader, 2006).

Mansour and Abdel Kader (2004) cleared that there is no doubt that Mega projects such as GEM "will act as a vehicle of accelerated society development." Indeed, "the way in which the presence of the GEM will impact the local environment poses planning questions which need to be addressed and challenged." the GEM will present many facilities to the neighboring community such as commercials and recreational zones. 
The importance of GEM museum on archaeological development zone: As its location has been belonged to a larger archaeological site which includes the Pyramids Panorama, El Hassana Reserve, Abu Rawash and Abu Sir, and the Saqqara site. Designing "green belt" as a sustainable urban buffer at the Western part of the Greater Cairo Region is essential to protect it from prevailing desert wind. This zone can be used for recreational activities as an archaeological strip, based upon the Urban Development Plan goal of the Great Cairo (Abdeen, 2021).

\section{Research Methodology}

The project aims to: - investing the elements of the place as a tourist attraction, and international entertainment - opening a global visual axis of the pyramids area - infrastructure networks and a network of modern roads and transportation connecting the city to Greater Cairo - connecting the Pyramids Plateau to the Great Egyptian Museum and developing the area around the pyramids to become an open museum - quality of life and urban with all the services required in the modern era for the residents of Giza governorate.

The relation between the tourism product (sightseeing, accommodation, transportation, so on) and tourists is an intermediary coming from tour operators and travel agencies. Within this framework, one of the main questions is "what is the expected situation of GEM regarding sustainability in general and tourism programs in particular"?

The sample was 30 participants (general managers, marketing directors) at some Egyptian agencies. Semi structured interviews were conducted as a guided conversation between the authors and interviewees. The selection of agencies depends on a set of criteria like:

-The agencies with highly represented among the gross tourism movement in Egypt.

-The leading travel agents in incoming tourism, however it is notably that a little number is accounted high percent from the gross volume of incoming tourism.

The interview method with a duration of forty-five minutes to one hour was conducted during March and April 2021.

All the interview participants were received the same questions, at. Depending on the interviewees' answers, additional questions were asked where we considered that a clarification or a deeper, more detailed elaboration of the items under discussion was required. It should be noted that all travel agencies included in the research were self-selected; these were big travel agencies with high market segment, ranking and image, financial resources with market stability.

\section{Results and Discussions}

All the interview participants have considered the GEM as an Egyptian sustainable organization. What differs significantly from one to another are their views on sustainability. From the thirty interviewed, twenty one were identified all the components of sustainability in this area, i.e. the socio-cultural, the financial, and the natural environment components; two of them identified only the cultural and the financial components, the rest of participants were associated sustainability with the existence of the resources that were necessary for the museum management. 
Most of the surveyed travel agencies consistently include in their tourism packages the visit of monuments and museums. The analysis made of the obtained information during the interview was made to meet the three groups of criteria for sustainable tourism.

The GEM will provide a new and different experience for visitors, as it is not a regular museum with monuments only, and the visitor will experience a variety of tourism, entertainment, or educational, and contains traces from the beginning of the ancient Egyptian History through the Greek and Roman times, as well as the special entertainment side for children, and the educational section of different ages. There is a website for the museum that has all the information related to the museum and it is available to give the tourist a clear and informative vision

It was strongly agreed by the sample (76\%) that the cultural resources of the community will be preserved by the GEM, not only for the current generation, but also for the future generations. Some were referred 67\% that GEM may contribute to assuring the sustainability of not only the cultural environment but also the natural one. Furthermore, 59\% advised that the museum will be a place that is able to serve the needs of people with special needs and disabilities. A sustainable source of income will be maintained because of the GEM and affect largely tourism industry income in this market segment. This was mentioned by the majority $(88 \%)$. Moreover, $89 \%$ clarified that the museum will raise the level of tourism services in Giza Governorate and will increase the number of tourists visiting the area. While $83 \%$ of the sample stated that, the grand museum will change the nature of tourism program map. While $79 \%$ revealed that the duration will be longer.

\section{The economic aspect}

GEM will be a development instrument that promotes economic growth by attracting visitors who are driven completely or partially by historical or heritage offerings, according to the majority of the respondents $(88 \%)$. GEM will encourage visitors to remain longer, maintain a sustainable source of income, and have a significant impact on tourism earnings, according to some respondents $(61 \%)$ because the interest in this type is coming from the key tourism markets.

About $52 \%$ stated that the visitors will comprise the general public as well as Egyptologists who are interested in "add-on" tourist opportunities and stay lengths. GEM will, in general, generate economic vitality, transform the nature of tourism programs, and enhance the Egyptian archaeological map, according to consensus.

The first phase was created only for the Sphinx Airport, there is a plan that this airport will become an international airport that serves the region as a whole, and will receive all kinds of aircrafts, of all sizes, in addition to bringing tourists with private planes or small planes, and that it will bring facilitation to the checking-out procedures for visitors of the museum. This will achieve a large number of tourists whether from Asia, Europe or America, as within minutes he/she will be able to reach the museum. Thus, facilitating the course of the visit, and while let the tourist reach the area of the Pyramids Plateau with ease, the process will be managed by Companies that are selected based on their qualifications in managing and operating museum facilities. 


\section{The Social aspect}

Since the establishment of the project, it created more than 10,000 jobs to workers and engineers, it is also said that it will indirect opportunities that exceed this figure by 1o times. Also, after the opening, there will be at least 2.000 jobs within the museum, as well as other opportunities based on tourism activities through bazaars, cafes, and restaurants that are near the GEM. Not to mention, the opportunities for simple employment that can provide services as taxis and tourist buses which will also help them increase their gains.

Some of the surveyed persons (59\%) revealed that the function and the location of GEM help to establish a privileged relationship with the monumental area of the pyramids and of the Sphinx, as well as all the other archaeological sites. The respondents (64\%) added that GEM will contribute to both conservation and development objectives along with social equality and cultural values. While $(61 \%)$ clarified that the museum will raise the level of tourism services in Giza Governorate. Around 54\% of the agents mentioned that GEM will provide residents with a great sense of belonging to their homeland, as well as intercultural awareness both inside and outside the community.

\section{The Environmental aspects}

Some responses (53\%) revealed that GEM will preserve the cultural resources of the community not only for the current generation, but also for the future ones. others referred (67\%) that it may contribute to assuring the sustainability of both the cultural and the natural environment. Furthermore, 59\% advised that the museum will be a friendly place for people with special needs and disabilities.

Some agents (19\%) emphasized that GEM has a minimum visual and environmental impact and respects the ecosystem and landscape of the place.

Regarding the potential negative impact of tourists' actions on historic remains and other cultural heritage features, the minority ensured (13\%) that foreign tourists know the rules and good practices. All agents have performance schools for tour guides who are actively involved in educating the tourist about the conservation of heritage areas. which is:

According to Egypt's Vision 2030, the project consists of several elements, the first of

1. GEM Hotels Area.

2. GEM Plaza Square.

3. Khufu Plaza and Oasis Arena and Oasis.

4. Open Sphinx Museum.

5. Sphinx Village (New Quail Lodge).

6. Khufu Avenue axis at a cost of about 100 billion pounds, located $8 \mathrm{~km}$ long and 600 meters wide and the project also serves the monorail train and will connect Sphinx Square with engineers to the Pyramids of Giza through the Street of the Arab League.

7. An urban belt for Giza that limits the supply of agricultural land by planning residential areas with the concept and quality of life that the residents of Giza deserve. 


\section{Conclusion}

Given the results, the community must take multiple steps and considerations. Some of them will be part of the integrated strategic planning process, others will be part of good project management.

1. GEM today is the tool of mass culture and sustainability.

2. Focusing on the cultural and heritage products themselves and supporting management and evaluation actions.

3. GEM is a social platform that combines the artistic life and culture of the area with its extensive exhibitions, concerts, libraries and shopping centers, and modern educational institutions.

4. The GEM Center for Arts and Crafts aims to provide visitors the opportunities through educational programs and workshops, thus reviving the reputation of traditional crafts. It will also provide space and facilities for local artists and artisans to create their creativity and support the artistic value of this increasingly important field.

5. The accessibility of all-around sites for people including those with handicaps, discounts to persons with disabilities.

6. Enhancing electronic media of the ministry of tourism, tour operators' websites, and so on.

7. Implementing sophisticated promotional plan, as the community needs to advertise its own "brand".

8. The GEM will represent the awareness and knowledge of professionals in museums all over the world. GEM will be eco and sustainable institution.

\section{References}

1. Abdeen, S., 2021. Analytical Methodology for Regenerating Urban Identity as a Sustainable Cultural Heritage Landmark in Egypt, Case Study: Egyptian Museum (GEM)" Engineering Research Journal, 169, pp.51-75.

2. Attia,A., Abd El Hady, D. El Manhaly. S., 2015.The Role of Dark Tourism in Developing the Demand For The Egyptian Tourist Product, Journal of Tourism Research,12 (1), pp.314.

3. Attia, A. and Abdel Kader, W., 2006. The Impact of Major National Projects on the Surrounding Residential Settlements: The Case of the Grand Egyptian Museum, XXXIV IAHS Conference, September 20-23, Naples.

4. Bonifica, S., 1999. Feasibility Study of the New Museum System, Italian Ministry of Foreign Affairs.

5. Codignola, F. and Mariani, P., 2017. Location Attractiveness as a Major Factor in Museum Visitor Choice and Satisfaction, Management Studies, 5(2), pp.75-90.

6. Colbert, F. 2003. Entrepreneurship and leadership in Marketing Arts. International Journal of Arts Management, 6(1), pp. 30-39.

7. Daniela, L., 2020. Virtual Museums as Learning Agents, Sustainability, 12(7), pp. 26982722. 
8. Department for Digital, Culture, Media \& Sport (DCMS), 2004. Sector Appendix: Museums, Libraries and Archives.

9. El Sheikh, S., 2020. Factors Affecting Pre-Visit Destination Image: Application on the Grand Egyptian Museum (GEM), Journal of Humanities and Applied Social Sciences, 2(3), pp. 215-234.

10. Grand Egyptian Museum (GEM) Authority Prequalification Document for the Facilities Management and Operation of the Grand Egyptian Museum (GEM) Complex. (2020). Available at http//:gem.gov.eg.

11. Günay, B., 2021. Museum Concepts from Past to Present and Important of Museums as Center of Art Education, Social and Behavioral Science, 55, pp.1250-1258.

12. Hawas, Z., 2005. A New Era for Museums in Egypt, in: Museum International, Heritage Landscape of Egypt, p.16.

13. Administration \& Conservation Center: El Mathf El Masry El Kebir, 2020. Available at http://gem.gov.eg/index/Project_overview.htm.

14. The Egyptian electronic portal of the Egyptian Ministry of Tourism and Antiquities, (2020). Egyptian Ministry of Tourism and Antiquities 2020 edition. Available at /http://www.antiquities.gov.eg.-2020.

15. International Council of Museums (ICOM), 2013. Code of Ethics for Museums. Last accessed March 10, 2021, from http://icom.museum.

16. ICOM, The International Council of Museums, 2007. "Museum Definition", availableat:http://icom.museum/who-we-are/thevision/museumdefinition. html

17. Kirchenblatt-Gimblett, B., 1998. Destination culture: Tourism, Museums, and Heritage. Berkeley, Los Angeles, London: University of California Press.

18. Labadi,S., Giliberto, F., Rosetti, I. Shetabi,L. and Yildirim, E., 2021. Heritage and the Sustainable Development Policy Guidance for Heritage and Development Actors, International Council on Monuments and Sites, pp.10.

19. Lopatovska,I.(2015), Museum Website Features, Aesthetics, and Visitors' Impressions: A Case Study of Four Museums, Museum Management and Curatorship, 30( 3), pp.191-207.

20. Mansour, Y, Shafik, Z and Abdel Kader, W., 2004. The Grand Museum of Egypt and the Challenge of Sustainability, A paper presented in the First Conference of the Architectural Department, Faculty of Engineering, Cairo University, "Sustainable Architecture \& Urban Development".

21. Mansour, Y., 2005. The Grand Museum of Egypt Project: Architecture and Museography, in: Museum International, Heritage Landscape of Egypt, LVII, 1(2), pp. 36-41.

22. Marandino, M., 2005. Museus de Ciências como espaços de educo. In: Museus: Dos Gabinetes de Curiosidade à Museografia Moderna, eds. B.G. Figueiredo \& D.G. Vidal (Belo Horizonte, Argumentum), pp.165 -175.

23. Mazen, N., 2006.Museums and Architecture, Unpublished Master's Thesis, Cairo University.

24. Ossama, W., 2005.The Nubia Museum's Role in the Community, in: Museum International, Heritage Landscape of Egypt, May, pp.68.

25. Pencarelli,T., Cerquetti,M. and Splendiani,S., 2016, The Sustainable Management of Museums, Tourism and Hospitality Management, 22(1), pp. 29.

26. Sandell, R. and Janes, R.,2007. Museum Management and Marketing, Routledge, New York, 10016, pp.187. 
27. Schweibenz, W., 2019.The Virtual Museum: an Overview of Its Origins, Concepts, and Terminology, The Museum Review, 4(1).

28. Styliani, S., a, Fotis ,L., Kostas ,K. and Petros ,P.,2009. Virtual Museums, A Survey and Some Issues for Consideration, Journal of Cultural Heritage, 10 (4), pp. 520-528.

29. Sustainable Development Report, 2020.Cambridge University Press, pp.11.

30. Tufts, S., and Milne, S. (1999). Museums: A Supply-Side Perspective. Annals of Tourism Research, 26(3), pp. 613-631.

31. United Nations, 2015. Transforming our World: The 2030 Agenda for Sustainable Development, pp.5.

32. United Nations, 2021. Financing for Sustainable Development Report, pp. 123-188.

33. The Grand Egyptian Museum: One of the Biggest Cultural Openings of 2020 the Style Mate. March 2020

Art \& Culture, Design. Available at www.thestylemate.com. 